\title{
Rietveld Structure Refinement of the Stilbite Crystals from Deccan Traps (India) Using X-ray Powder Diffraction Data
}

\begin{abstract}
GHEORGHE BRANOIU*, IBRAHIM RAMADAN
Petroleum-Gas University of Ploiesti, 39 Bucharest Blvd., 100680, Ploiesti, Romania

The crystal structure of a spectacular sample of stilbite from Pune region located in the Deccan Traps (western India) has been refined using X-Ray powder diffraction data and the Rietveld method. The Rietveld refinement was carried out using the computer program Diffracplus TOPAS 4.1. The pseudo-Voigt (pV) profile function was used for the fit of the peaks. The Rietveld refinement of the analyzed sample in the space group $\mathrm{C} 2 / \mathrm{m}$ (No.12): $a=13.606 \AA, b=18.260 \AA, c=11.253 \AA, \beta=127.432^{\circ}, Z=8$, confirm the basic stilbite structure. The chemical composition of the stilbite crystals from Pune region (India) was determined by EDX analysis. The paper presents a new set of the unit cell parameters and fractional coordinates that define the stilbite crystal structure. The quality of the sample analyzed was pristine, the sample being collected from an association of apophyllite-stilbite crystals of centimetric dimensions.
\end{abstract}

Key words: stilbite, crystal structure, X-rays diffraction, EDX, Rietveld method

The Deccan Traps (Deccan Plateau), located in westcentral India, is one of the Earth's largestigneous provinces, covering over half a million sqkm, and consists of massive tholeiitic basaltic lava flows in the late Cretaceous as a result of rifting betw een India and Seychelles. The Deccan Traps are thickest in the western part of India $(2,000 \mathrm{~m}$ thick) while towards east become thinner (less than 100 $\mathrm{m})$. The west-central part of the Indian peninsula is dominated by flood basalts which form a prominent terraced landscape called traps [1, 2].

The basaltic lava flows contain vesicles, joints and weathered cappings usually filled with secondary minerals like zeolites, carbonates and secondary silica (i.e. agate), the most encountered minerals being heulandite, stilbite, mordenite, apophyllite, mesolite, epistilbite, calcite and chabazite. [2, 3]. Sukheswala et al. [3] and later J effery et al. [4] investigated zeolite species in the Nasik and Pune regions located in the Deccan Traps, north and south from Bombay.

Stilbite is one of the first zeolites mentioned by Hauy since 1801. Stilbite is quite widespread and generally it occurs as secondary mineral in low-temperature hydrothermal paragenesis, in amygdules and cavities in basalts, andesites, and various metamorphic rocks. It is almost always occurs together with other zeolites like heulandite and apophyllite, especially in the trap rock environments. Stilbite commonly occurs as white/clear plates, globes, radial structures and thin tabular, flattened on (001), and rhombic cruciform crystals, almost always twinned. Usually, stilbite form aggregates of radiating plates characterized by the presence of six-sided rhombic plates. The stilbite is colorless (if is pure) but it is more often colored yellow, pink, red orange or brown by impurities (Fe and $\mathrm{Mn}$ ions), with vitreous to pearly luster on cleavage. Whether it is a bow-tie or wheat-sheaf shape, stilbite can be a handsome specimen with its unique pearly luster and often colorful pink shades. The best crystals, up to $12 \mathrm{~cm}$ long, are encountered in the Pune (Poona) and Nasik regions [3-6].

The mineral sample used in the study ( fig. 1) belongs to the collection of Mineralogy Laboratory of the PetroleumGas University of Ploiesti. Macroscopically the stilbite crystals are vitreous to pearly, peach colored, the crystal blades of tabular habit forming sheaf-like or bow-tie aggregates of medium to large size ( 1 to $6 \mathrm{~cm}$ ). Frequent the sheaf-like aggregates have crystal faces on the end. The cleavage is perfect on (010) and the Mohs hardness is 3 to 4.

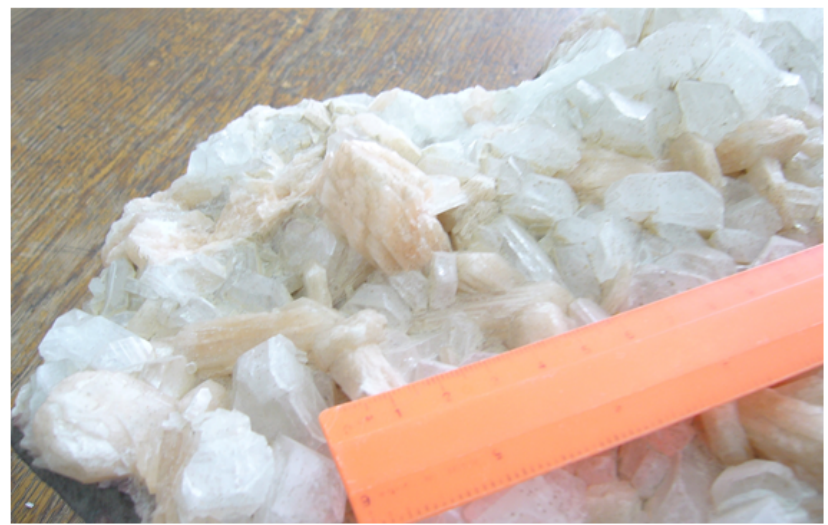

Fig. 1. Apophyllite-stilbite association from Pune region (India) in the collection of Mineralogy Laboratory of the Petroleum-Gas University of Ploiesti

Zeolites aroused in the last century a great interest for science and technology due to their wide commercial uses for ion-exchange, molecular sieving, filtration, adsorption, and as chemical catalyst in industrial, agricultural, environmental, and biological technology, such as water and gas purification systems, petrochemical and chemical industries, radioactive-waste-removal mediums, laundry detergents, animal feeds, soil amendments, carriers for pesticides and fungicides, odor control, oil absorbent and greenhouse gases emissions capture and sequestration. The wide use of the zeolites in industry is a consequence of their readily available source in various geological settings, the low cost and ecological compatibility. The nomenclature of the zeolite minerals group (over 80 mineral species) was reviewed by the International Mineralogical Association (IMA) more than 20 years ago. The term zeolites refers to a specific group of hydrous aluminosilicates having an infinite, open, threedimensional crystal structure acting as molecular sieves capable of adsorbing and absorbing differenttypes of gases, moistures, petrochemicals, heavy metals, radioactive elements and a multitude of various solutions. The crystal structure of zeolites is characterized by a framework of

*email: gbranoiu@yahoo.com, Phone: 0763662593

REV.CHIM.(Bucharest) $70 \bullet$ No. 7 2019

http://www.revistadechimie.ro 
linked tetrahedra, each consisting of four 0 atoms surrounding a cation. This framework contains open cavities in the form of channels and cages. These are usually occupied by water molecules and extra-framework cations that are commonly exchangeable. The channels are large enough to allow the passage of guest species. In the hydrated phases, dehydration occurs at temperatures mostly below about $400^{\circ} \mathrm{C}$ and is largely reversible. The framew ork may be interrupted by $(\mathrm{OH}, \mathrm{F})$ groups; these occupy a tetrahedron apex that is not shared with adjacent tetrahedron [5-9].

Stilbite is one of the most common zeolites with threedimensional open structure (STI framework type) having monoclinic symmetry in $\mathrm{C} 2 / \mathrm{m}$ space group. The STI framework type of the stilbite group, which includes stilbite series, stellerite, and barrerite, consists of two sets of connected channels. The stilbite crystal structure (fig. 2) is built of $\mathrm{SiO}_{4}$ and $\mathrm{AlO}_{4}$ tetrahedra fully cross-linked by $\mathrm{O}$ atoms with other tetrahedra (practically, each oxygen is shared between two tetrahedra) and is characterized by large intersecting, relatively open channels of 10-member and 8-member tetrahedral rings parallel to a-axis and caxis respectively. The arrangement of tetrahedra leads to large open spaces (or cages), typically 3-6 $\AA$ diameter, which are interconnected to form two sets of continuous channels extending throughout the crystal. The interconnected channel system it consists of large channels (4.1 $\times 6.2$ A diameter) bordered by ten-membered rings of (Si,Al) $\mathrm{O}$ tetrahedra intersecting the smaller channels ( 2.7 $\times 5.7 \AA$ diameter) bordered by eight-membered rings of ( $\mathrm{Si}, \mathrm{Al}) \mathrm{O}_{4}$ tetrahedra. The largest channels extends parallel to the $a$-axis and is confined by a ten-membered rings. The smaller channels is located along [101] for monoclinic frameworks or [001] for orthorhombic structure and is confined by an eight-membered rings that are two types: equant and narrow elongate. Both types are parallel to the $a b$-plane, have mirror symmetry across the planes at $b=$ $0,1 / 2$, and alternate in the a-direction. The equant rings form a channel parallel to $c$-axis at $128^{\circ}$ to the tenmembered ring channel. Elongate and equant rings alternate to form a restricted channel parallel to pseudoorthorhombic $c$-axis. The largest portion of the channels contains the equant 8-member ring and the smaller portion of the channels contains the narrow elongated 8-member ring. Both of these largest and smaller channels are in the (010) plane, creating a structural weakness across the plane leading to perfect (010) cleavage and a tabular habit. Because of the substitution of $\mathrm{Al}^{3+}$ for $\mathrm{Si}^{4+}$ in the tetrahedral framework, there is a negative charge that is balanced by cations such as $\mathrm{Na}, \mathrm{K}, \mathrm{Ca}$ and $\mathrm{Mg}$ that reside in the cages and channels of the framew ork. Water molecules may also reside in these channels and can be removed by heating withoutdamage to the crystal structure. The open channels allow water and large ions to travel into and out of the crystal structure. The size of these channels controls the size of the molecules or ions and therefore a zeolite like stilbite can act as a molecular sieve. Unlike most related zeolites the Ca ions are near the middle of the channel surrounded by and bonded to eight water molecules but no framework oxygens. The Ca site contains a small amount of $\mathrm{Na}$ and the three partially occupied $\mathrm{Na}$ sites and another partially occupied metal site (probably Mg) [5-7, 10-13, 15-17, 20]

The stilbite crystal structure aroused a great interest since the middle of the last century because of the importance of this type of zeolite in numerous commercial processes due to readily available source in various geological settings, the low cost and ecological

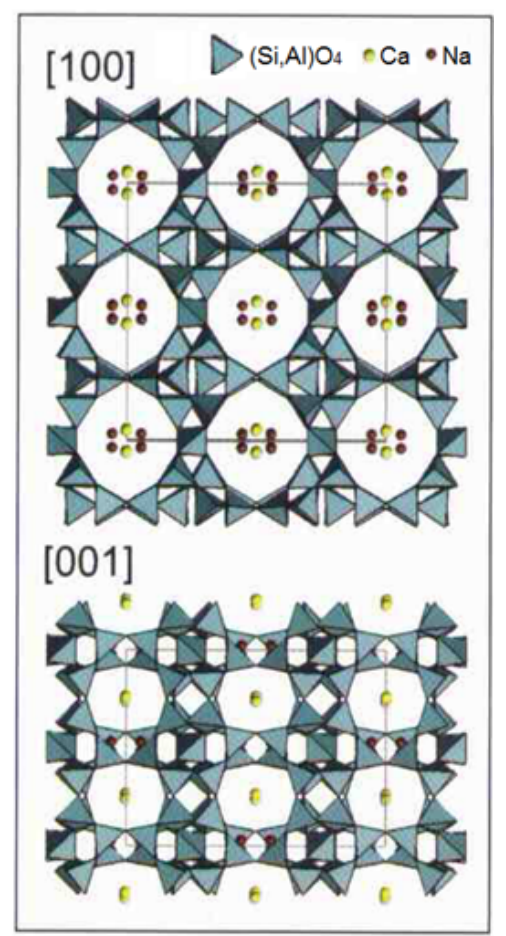

Fig. 2. Stilbite crystal structure projected on [100] in the top, and on [001] in the bottom. The unit cell is outlined [6]

compatibility. X-ray diffraction studies of the stillbite crystal structure were made by numerous authors. $[3,10-20]$. The crystal structure of stilbite was initially partially solved by Galli and Gottardi [11], and was refined subsequently in the space group $\mathrm{C} / \mathrm{m}$ by Slaughter [10] and Galli [12]. Later Mortier [15] and Akizuki and Konno [16] also carried out a refinement of stilbite crystal structure in the space group C2/m (monoclinic symmetry). Passaglia et al. [13] and later, Quartieri and Vezzalini [17] reported a refinement of stilbite crystal structure using the pseudo-orthorhombic F2/m setting. Akizuki et al. [18] also studied the symmetry of different growth sectors in stilbite by single-crystal diffraction and refined the structure of an orthorhombic $\{001\}$ growth sector yielding space group $\mathrm{Fmmm}$, within a chemically homogeneous crystal. Cruciani et al. [19] was studied the dehydration dynamics of stilbite using synchrotron X-ray powder diffraction starting from the parameters and atomic coordinates described by Galli [12] and Quartieri and Vezzalini [17]. In their refinements, Galli [12] and Akizuki et al. [18] implied complete (Si,Al) disorder based upon average T-0 distances, while Slaughter [10] and Quartieri and Vezzalini [17] assumed pronounced (Si,Al) ordering, with Al contents varying between 11 and $40 \%$ in the different tetrahedral sites.

In our paper we carried out a chemical-mineralogical investigation using X-rays diffraction and EDX analysis and a Rietveld structure refinement on a spectacular stilbite sample (fig. 1) from Pune region located in the famous Deccan Traps (western India).

\section{Experimental part}

The stilbite crystals were grinded in an agate mortar with pestle by fine grinding. X-ray powder diffraction data were measured at $24^{\circ} \mathrm{C}$ using an automated Bruker D8 Advance $\theta-\theta$ diffractometer, with CuKa radiation $(\lambda=$ $1.54 \AA$; $40 \mathrm{kV} ; 40 \mathrm{~mA}$ ), a LynxEye detector and BraggBrentano geometry. $\mathrm{K} \beta$ radiation was eliminated by a $\mathrm{Ni}$ filter. Primary and secondary Soller slits were $2.5^{\circ}$. A fixed aperture and divergence slit of $0.6 \mathrm{~mm}$, a $0.6 \mathrm{~mm}$ antidivergence slit and $0.1 \mathrm{~mm}$ width detector slit were used. X-ray diffraction data were obtained using $0.1^{\circ} 2 \theta$ steps from $5^{\circ}$ to $60^{\circ} 2 \theta$ counting for $10 \mathrm{~s}$ per step. The Rietveld refinement was carried out using Diffracplus 
Table 1

AVERAGE CHEMICAL COMPOSITION OF THE STILBITE CRYSTALS (EDX ANALYSIS)

\begin{tabular}{|c|c|c|}
\hline Element & $W t \%$ & Standard deviation $(\sigma)$ \\
\hline $\mathrm{Si}$ & 27.88 & 0.20 \\
\hline $\mathrm{Ca}$ & 5.73 & 0.10 \\
\hline $\mathrm{Na}$ & 0.82 & 0.10 \\
\hline $\mathrm{Al}$ & 7.76 & 0.10 \\
\hline $\mathrm{O}$ & 57.81 & 0.20 \\
\hline TOTAL & 100.00 & \\
\hline
\end{tabular}

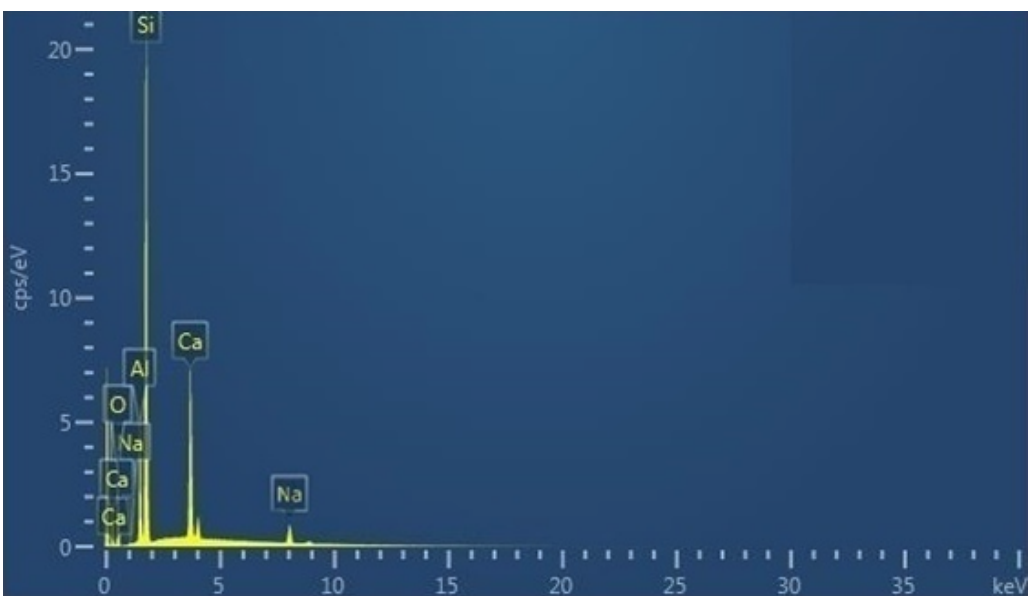

Fig. 3. EDX analysis of the stilbite sample

Table 2

TOPAS 4.1 software. Qualitative analysis was performed using Diffracplus EVA software with Search/Match program and PDF-ICDD 2-2008 database. Identification of crystalline phases (minerals) was made using best quality marks: $\left(^{*}\right)$ (=high quality), after removing the background and $\mathrm{K} \alpha 2$ radiation.

The stilbite sample was also analyzed by SEM/EDX using a Hitachi S3400-N microscope equipped with an Oxford Instruments $X$-act energy dispersive $X$-ray (EDX) spectrometer, operated using the Inca software package. The generated spectra (fig. 3) were determined and analyzed by an EDX spectrometer, with $125 \mathrm{eV}$ resolutions, and detector active area $10 \mathrm{~mm}^{2}$. During tests, the working conditions were kept stable in order to minimize any effect on the statistical nature of the production of radiation.

In table 1 is presented the average chemical composition obtained by EDX analysis carried out on several powders from the stilbite sample.

\section{Results and discussions}

Pseudo-Voigt (pV) profile function was used for the fit of the peaks; the result of measurement shows that the peaks shape is Lorentzian. Rietveld refinement using X-ray powder diffraction data of stilbite sample in the space group $C 2 / m$ (No.12) [21]: $a=13.606 \AA, b=18.260 \AA$, $c=11.253 \AA, \beta=127.432^{\circ}, Z=8, \operatorname{Rwp}=9.61, \operatorname{Rexp}=8.13$, $\mathrm{Rp}=7.57$, confirm the basic stilbite structure. The figures of merit[22, 23], represented by goodness-of-fitGOF (Rwp/ Rexp) and Durbin-Watson d-statistic (DW), were
METERS REFINEMENT OF THE STILBITE SAMPLE ANALYZED

\begin{tabular}{|c|c|c|}
\hline Parameter & Value & 2-sigma \\
\hline$a(\mathrm{~A})$ & 13.606 & 0.024 \\
\hline$b(A)$ & 18.260 & 0.032 \\
\hline$c(\mathrm{~A})$ & 11.253 & 0.019 \\
\hline$\left.\beta()^{\circ}\right)$ & 127.432 & 0.089 \\
\hline Cry size L (nm) & 406.80 & 0.026 \\
\hline Cry density $\left(\mathrm{g} / \mathrm{cm}^{\prime} 3\right)$ & 2.225 & 0.065 \\
\hline Cell Volume $\left(\mathrm{A}^{3} 3\right)$ & 2220.421 & 0.037 \\
\hline R Bragg & 14.905 & - \\
\hline Rwp (\%) & 9.61 & - \\
\hline $\operatorname{Rexp}(\%)$ & 8.13 & - \\
\hline $\mathrm{Rp}(\%)$ & 7.57 & - \\
\hline GOF & 1.18 & - \\
\hline DW & 2.07 & - \\
\hline
\end{tabular}

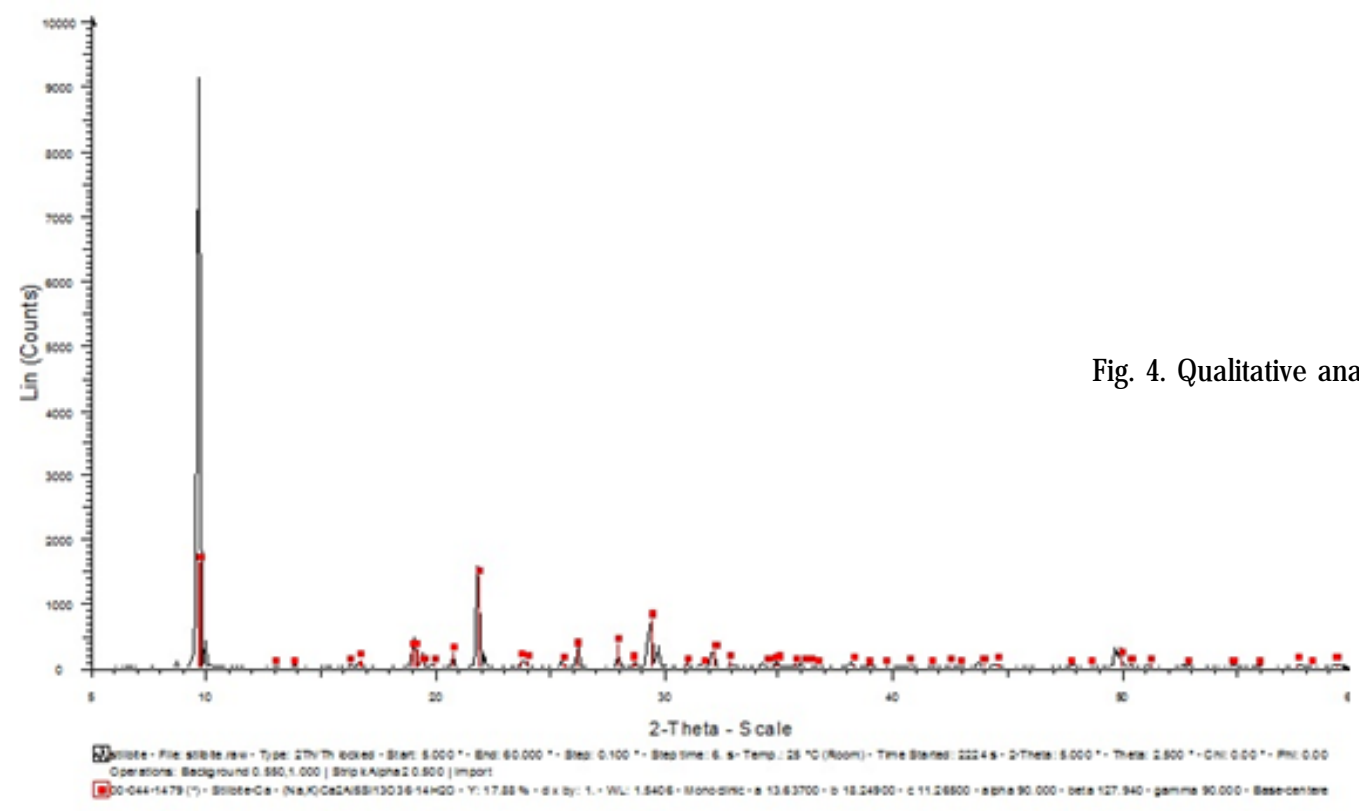




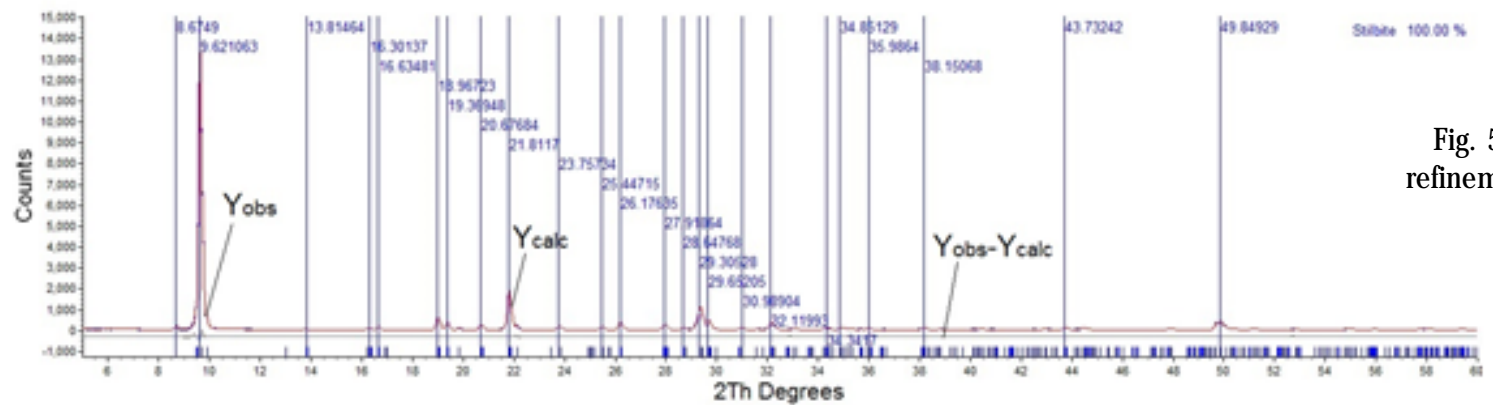

Fig. 5. Final Rietveld refinement of the stilbite sample

$\mathrm{GOF}=1.18$ and $\mathrm{DW}=2.07$, both indicating a good refinement. The parameters which represent the quality of the Rietveld refinement are presented in table 2.

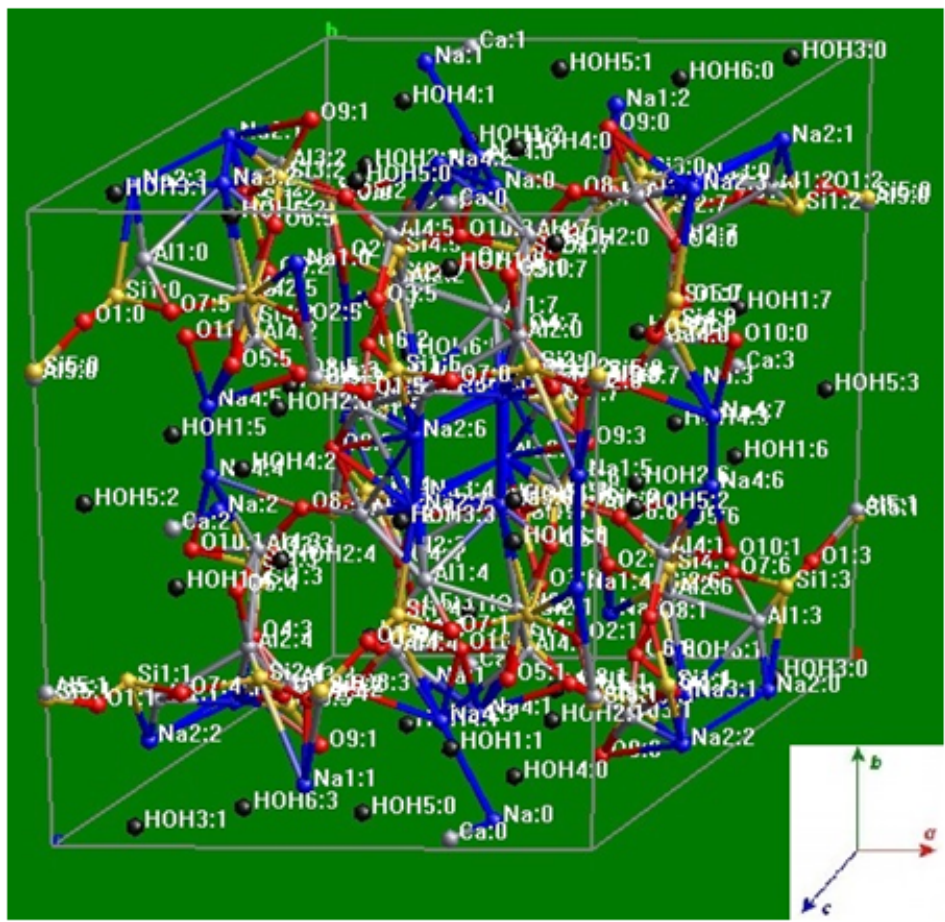

Fig. 6. The position and the bonds between the atoms in the stilbite structure resulted in the refinement

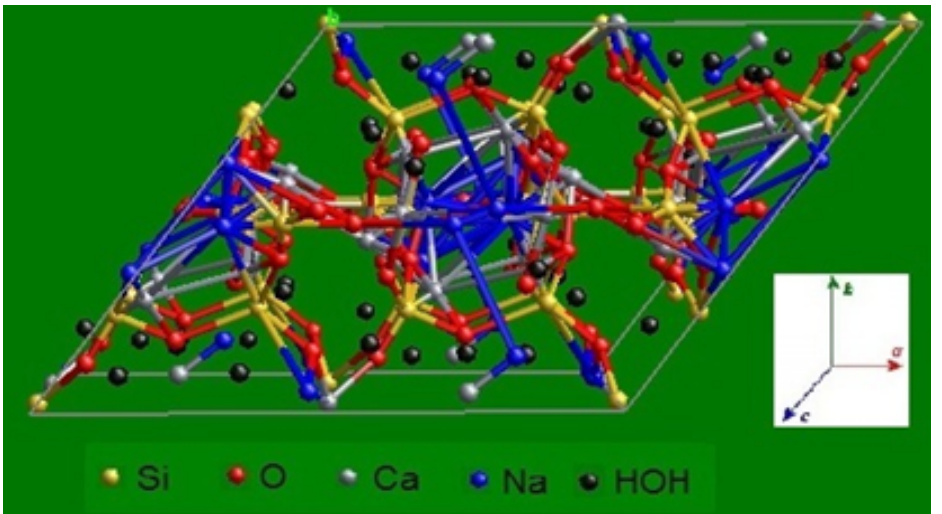

Fig. 7. The projection of the STI framework of stilbite (bond lengths) on ac plane resulted in the refinement

Qualitative analysis of the stilbite sample analyzed is presented in figure 4. Graphical representation of final Rietveld refinement of the stilbite sample analyzed showing the observed data (Yobs), the calculated data (Ycalc) and the difference between them (Yobs-Ycalc), is presented in figure 5.

The position of the atoms and the bonds between atoms in the refined structure of stilbite is shown in figure 6 and figure 7. Stilbite is a STI framework type characterized by large intersecting, open channels of 10-membered and 8membered tetrahedral rings. In this framework the average values for bridging ( $\mathrm{Si}, \mathrm{Al}$ )- $\mathrm{O}$ bond lengths for the $\mathrm{T} 1, \mathrm{~T} 2, \mathrm{~T} 3$, T4 and T5 tetrahedra are 1.671, 1.664, 1.663, $1.656 \AA$ and $1.652 \AA$ respectively. Other interatomic distances (average values) are the non-bridging bond lengths $0-0$ in the range 2.667-2.696 $\AA$; $\mathrm{Ca}(\mathrm{Na})-\mathrm{HOH} 2.474 \AA$; $\mathrm{Ca}(\mathrm{Na})-0$ 4.312A;

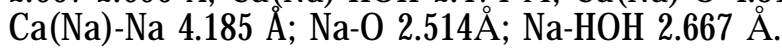

The atomic positional parameters for the stilbite structure resulted from the Rietveld refinements are presented in table 3. A three-dimensional view of the coordination polyhedron in the refined structure of stilbite is shows in figures 8 and 9. 
Table 3

ATOMIC POSITIONAL PARAMETERS FOR THE STILBITE CRYSTAL STRUCTURE RESULTED IN THE RIETVELD REFINEMENT

\begin{tabular}{|l|l|l|l|l|l|l|l|}
\hline Atom & Np & $\mathbf{x}$ & $\mathbf{y}$ & $\mathbf{z}$ & Occ & Beq & $\begin{array}{c}\text { s- } \\
\text { sigma }\end{array}$ \\
\hline Al1 & 8 & 0.98251 & 0.19491 & 0.23871 & 0.659 & 0.704 & 0.0233 \\
\hline Si2 & 8 & 0.98251 & 0.19491 & 0.23871 & 0.339 & 0.704 & 0.0233 \\
\hline Al2 & 8 & 0.24632 & 0.30355 & 0.25543 & 0.801 & 0.883 & 0.0248 \\
\hline S13 & 8 & 0.24632 & 0.30355 & 0.25543 & 0.193 & 0.883 & 0.0248 \\
\hline Al3 & 8 & 0.18292 & 0.07867 & 0.51575 & 0.721 & 0.941 & 0.0279 \\
\hline Si4 & 8 & 0.11430 & 0.30532 & 0.50000 & 0.765 & 0.699 & 0.0749 \\
\hline A14 & 8 & 0.11430 & 0.30532 & 0.50000 & 0.237 & 0.699 & 0.0749 \\
\hline Si5 & 4 & 0 & 0.25060 & 0 & 0.773 & 0.941 & 0.0674 \\
\hline A15 & 4 & 0 & 0.25060 & 0 & 0.221 & 0.941 & 0.0674 \\
\hline Ca & 4 & 0.28854 & 0 & 0.04920 & 0.854 & 1.251 & 0.0423 \\
\hline Na & 4 & 0.28854 & 0 & 0.04920 & 0.146 & 2.851 & 0.0423 \\
\hline Na1 & 8 & 0.51559 & 0.08911 & 0.94583 & 0.163 & 2.851 & 0.0679 \\
\hline Na2 & 8 & 0.11325 & 0.05894 & 0.64198 & 0.026 & 2.851 & 0.0679 \\
\hline Na3 & 8 & 0.08706 & 0.08706 & 0.52415 & 0.031 & 2.851 & 0.0679 \\
\hline Na4 & 8 & 0.47379 & 0.05594 & 0.52020 & 0.033 & 2.851 & 0.0679 \\
\hline O1 & 8 & 0.96985 & 0.19738 & 0.11093 & 1 & 1.360 & 0.0529 \\
\hline O2 & 8 & 0.09634 & 0.25133 & 0.13924 & 1 & 1.272 & 0.0296 \\
\hline O3 & 8 & 0.06526 & 0.27567 & 0.33522 & 1 & 1.510 & 0.0654 \\
\hline O4 & 8 & 0.04055 & 0.14647 & 0.36797 & 1 & 1.371 & 0.0748 \\
\hline O5 & 8 & 0.31712 & 0.21897 & 0.31455 & 1 & 1.620 & 0.0567 \\
\hline O6 & 8 & 0.27536 & 0.37384 & 0.38891 & 1 & 1.789 & 0.0655 \\
\hline O7 & 8 & 0.34797 & 0.30209 & 0.17142 & 1 & 1.490 & 0.0416 \\
\hline O8 & 8 & 0.30383 & 0.10746 & 0.51845 & 1 & 1.639 & 0.0261 \\
\hline O9 & 4 & 0.22252 & 0 & 0.47899 & 1 & 1.935 & 0.0459 \\
\hline O10 & 4 & 0 & 0.33021 & 0.50 & 1 & 1.726 & 0.0667 \\
\hline HOH1 & 8 & 0.33333 & 0.12055 & 0.13993 & 0.856 & 3.677 & 0.3236 \\
\hline HOH2 & 8 & 0.18558 & 0.12113 & 0.18397 & 0.693 & 3.145 & 0.2645 \\
\hline HOH3 & 4 & 0.10 & 0 & 0.90236 & 0.871 & 3.837 & 0.2668 \\
\hline HOH4 & 4 & 0.33077 & 0 & 0.36750 & 0.855 & 3.621 & 0.2525 \\
\hline HOH5 & 4 & 0.51736 & 0 & 0.27716 & 0.621 & 3.984 & 0.3790 \\
\hline HOH6 & 8 & 0.30169 & 0.03253 & 0.89970 & 0.429 & 3.576 & 0.3123 \\
\hline & & & & & & & \\
\hline
\end{tabular}

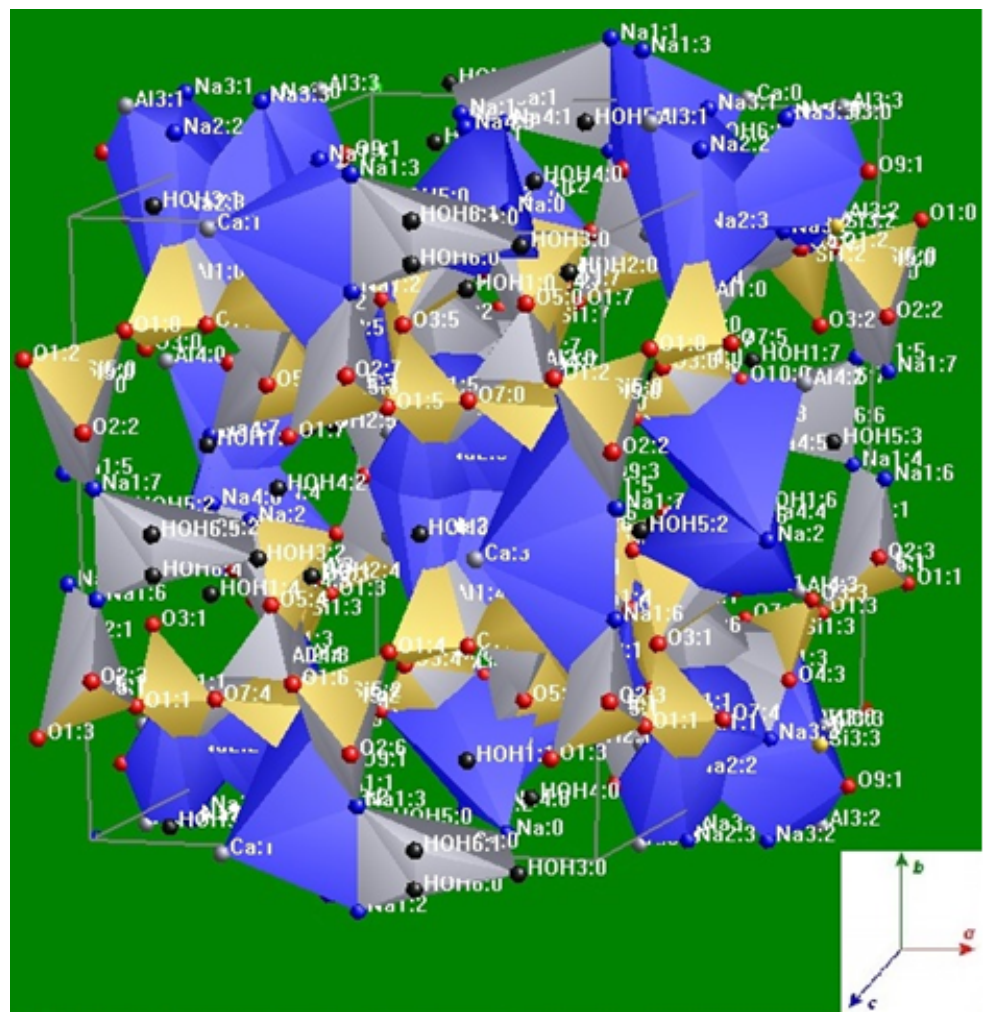

Fig. 8. The three-dimensional structure of the stilbite sample resulted in the Rietveld refinement 


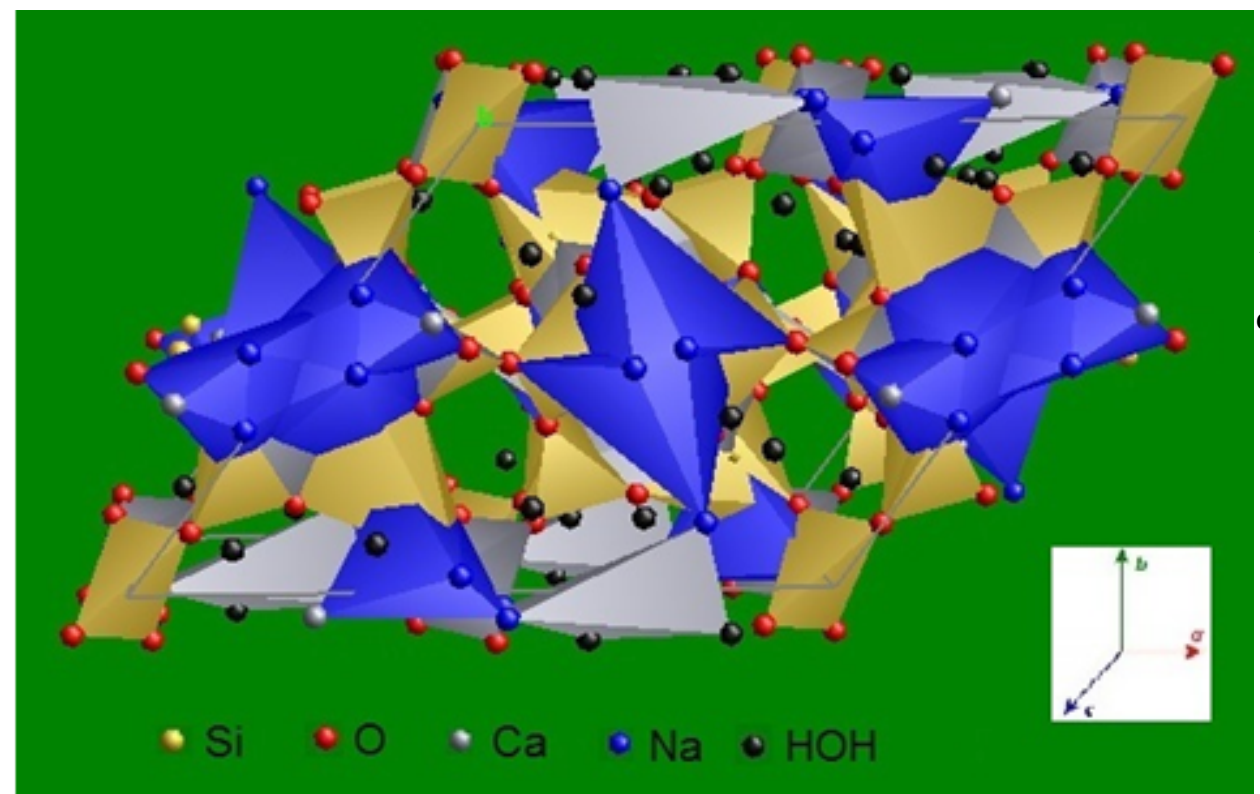

Fig. 9. Projection of the STI framework of stilbite (coordination polyhedron) on ac plane resulted in the refinement

\section{Conclusions}

The crystal structure of stilbite from Deccan Traps (Pune region, India) was refined by the Rietveld method using Xray pow der diffraction data. The stilbite crystal structure is a typical STI framework type characterized by large intersecting, relatively open channels ( $3-6 \AA$ diameter) of 10-member and 8-member tetrahedral rings. The results led to the conclusion that the stilbite sample belongs to space group $\mathrm{C} 2 / \mathrm{m}$ and confirmed the basic stilbite structure. The figures of merit were goodness-of-fit $\mathrm{GOF}=1.18$ and Durbin-Watson $d$-statistic $\mathrm{DW}=2.07$, both indicating a good refinement. The unit cell parameters resulted from the Rietveld refinement of the stilbite sample were: $a=13.606 \AA, b=18.260 \AA, c=11.253 \AA, \beta=127.432^{\circ}$, $Z=8$.

The paper provides a new set of the unitcell parameters and fractional coordinates that define the stilbite structure.

After performing the Rietveld structure refinement and EDX analysis we can give for the stilbite crystals from Pune region (India) the following chemical formula: $\mathrm{Na}_{0.40} \mathrm{Ca}_{4.02} \mathrm{Al}_{9.05} \mathrm{Si}_{27.06} \mathrm{O}_{72} \cdot 29.79 \mathrm{H}_{2} \mathrm{O}$.

\section{References}

1.SORKHABI, R., History Carved Out of the Deccan Traps, GEO ExPro, 7, 6, 2010, p. 66.

2.SINGHAL, B.B.S., Hydrogeological characteristics of Deccan trap formations of India, In Hard Rock Hydrosystems, Proceeding of Rabat Symposium, IAHS Publ. no. 241, 1997, p. 75.

3.SUKHESWALA, R.N., AVASIA, R.K., GANGOPADHYAY, M., Zeolites and associated secondary minerals in Deccan Traps of Western India. Mineralogical Magazine. 39, 1974, p. 658

4.J EFFERY, K.L., HENDERSON, P., SUBAREA, K.V., WALSH, J.N., The zeolites of Deccan basalts - a study of their distribution. In Deccan Flood Basalts (ed. Subarea, K.V.), Geological Society of India, Bangalore, 1988, p. 151.

5.COOMBS, D.S. et al., Recommended nomenclature for zeolite minerals: Report of the Subcommittee on zeolites of the International Mineralogical Association, Commission on New Minerals and Mineral Names, The Canadian Mineralogist, 35, 1997, p. 1571

6.RAKOVAN, J., Zeolite. Rocks \& Minerals, 79, 2004, p. 271
7.MISHRA, M., JAIN, S.K., Properties and applications of zeolites: A Review. Proceedings of the National Academy of Sciences India, Section B-Biological Sciences, 81, 2011, p. 250

8.DELVINGS, The Newsletter of the Delvers Gem \& Mineral Society, 70, 2, 2017, p. 7.

9.BUMBAC, GH., BOMBOS, D., CO Capture on Zeolites for Sustainable Energy Production, Rev. Chim. (Bucharest), 66, no. 11, 2015, p. 1891 10.SLAUGHTER, M., Crystal structure of stilbite, American Mineralogist, 55, 1970, p. 387

11.GALLI, E., GOTTARDI, G., The crystal structure of stilbite, Mineralogica et Petrographica Acta (Bologna), 12, 1967, p. I

12.GALLI, E., Refinement of the crystal structure of stilbite. Acta Crystallographica, B27, 1971, p. 833

13.PASSAGLIA, E., GALLI, E., LEONI, L., ROSSI, G., The crystal chemistry of stilbites and stellerites. Bulletin de Mineralogie, 101, 1978, p. 368 14.TANIGUCHI, M., ABE, T., Stilbite from Bomeki, Miyagi Prefecture, J apan, J ournal of the J apanese Association of Mineralogists, Petrologists and Economic Geologists, 76, 1981, p. 324

15.MORTIER, W.J ., Thermal stability of the stilbite-type framework: crystal structure of the dehydrated sodium/ammonium exchange form, American Mineralogist, 68, 1983, p. 414

16.AKIZUKI, M., KONNO, H., Order-disorder structure and the internal texture of stilbite, American Mineralogist, 70, 1985, p. 814

17.QUARTIERI, S., VEZZALINI, G., Crystal chemistry of stilbites: structure refinements of one normal and four chemically anomalous samples. Zeolites, 7, 2, 1987, p. 163

18.AKIZUKI, M., KUDOH, Y., SATOH, Y., Crystal structure of the orthorhombic $\{00 \mid\}$ growth sector of stilbite, European Journal Mineralogist, 5, 1993, p. 839

19.CRUCIANI, G., ARTIOLI, G., GUALTIERI, A., STAHL, K., HANSON, J.C., Dehydration dynamics of stilbite using synchrotron X-ray powder diffraction, American Mineralogist, 82, 1997, p. 729

20.J HA, B., SINGH, D.N., Fly Ash Zeolites, Advanced Structured Materials, Springer, 78, 2016, p. 5

21.HAHN, Th., International Tables for Crystallography, Volume A, 5th Edition, Space Group Symmetry (IUCr Series). Springer. 2005, p. 168. 22.YOUNG, R.A., The Rietveld Method, Oxford University Press, 1996, p. 21

23.PECHARSKY, V.K., ZAVALIJ , P.Y., Fundamentals of Pow der Diffraction and Structural Characterization of Materials, Second Edition, Springer, 2009, p. 521

Manuscript received: 5.09 .2018 